\title{
Corticosteroids as long-term regulators of the insulin effectiveness in mouse $3 T 3$ adipocytes
}

\author{
J. P. M. van Putten, Tj. Wieringa and H. M.J.Krans \\ Laboratory for Diabetes Research of the Department of Endocrinology and Metabolic Diseases, University Hospital, Leiden, The Netherlands
}

\begin{abstract}
Summary. Since corticosteroid treatment is often accompanied by insulin resistance, we explored the role of corticosteroids in the regulation of the insulin effectiveness in cultured 3T3 (mouse) adipocytes. Exposure of the fat cells to dexamethasone or corticosterone (0-5 days) induced a time-, concentration-, and protein synthesis-dependent and reversible decrease in insulin binding and in basal and insulinstimulated 2-deoxyglucose uptake. The decrease in binding $(50 \%)$ was primarily due to a decrease in receptor affinity i.e. to an increase in the rate of dissociation of insulin from its receptors, and was independent from the effects of $\mathrm{pH}$ and temperature on the affinity. The reduction in the 2-deoxyglucose uptake $(30-50 \%)$ was due to a decrease in the hexose transport capacity rather than to a decrease in the phosphorylation component of the 2-deoxyglucose uptake process. Lineweav-
\end{abstract}

er-Burk analysis revealed the dexamethasone induced a decrease in the apparent $V_{\max }$ of the transport system i.e. in the number or activity of the hexose transporters. The effect of dexamethasone seemed to be superimposed on that of longterm insulin treatment, suggesting a different mechanism. It is concluded that corticosteroids act as long-term regulators of the insulin effectiveness by influencing the rate at which insulin dissociates from its receptors and by altering the number or activity of the hexose transporters by a common mechanism, which differs from that of the long-term regulatory effect of insulin.

Key words: Insulin binding, corticosteroids, cultured 3T3 adipocytes, hexose uptake, hexose transport characteristics, cycloheximide, insulin.
Corticosteroid-induced insulin resistance is a wellknown phenomenon [1]. Corticosteroid administration in vivo is accompanied by both receptor and post-receptor alterations in various cell types [2-5]. Generally, insulin binding as well as insulin-sensitive glucose uptake and oxidation are decreased. The relationship between corticosteroids and insulin receptor binding in vitro appears to be more complex. In isolated fat cells and adipose tissue explants, incubation with corticosteroids for 2-48 h does not affect insulin receptor binding [6-8]. In cultured cells, on the other hand, corticosteroids have been reported to affect insulin binding, although not uniformly. In cultured lymphocytes [9] and in fibroblasts [10] corticosteroids enhance insulin receptor binding, whereas in cultured adipocytes insulin binding is decreased [11]. The relationship between corticosteroids and the activity of insulin-sensitive hexose uptake in vitro, on the other hand, is less variable and appears to resemble the relationship observed in vivo. Corticosteroids decrease insulin-sensitive hexose uptake in isolated fat cells [12], adipose tissue explants [7] and cultured adipocytes [11]. The mechanism by which these alterations in hexose uptake are mediated, however, is still unclear.

In the present study, we attempted to unravel the role of corticosteroids in the regulation of the insulin binding, hexose uptake and insulin response, using cultured 3T3 (mouse) adipocytes [13, 14]. This insulin-sensitive cell culture system has previously been shown to be a suitable model for the study of long-term regulation of insulin effectiveness [10,11, 15-17].

\section{Materials and methods}

\section{Cell culture}

3T3- $\mathrm{L}_{1}$ pre-adipocytes (Flow laboratories, Irvine, Ayrshire, UK) were grown and differentiated into adipocytes as described previously [15]. For studying the effects of cortocosteroids on the insulin effectiveness, fully differentiated $3 \mathrm{~T} 3$ adipocytes were cultured in standard medium in the presence or absence of dexamethasone for up to 5 days.

\section{Insulin binding}

Fully differentiated fat cells $\left(60 \mathrm{~mm}\right.$ wells, $2 \times 10^{6}$ cells) were washed

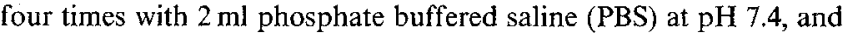




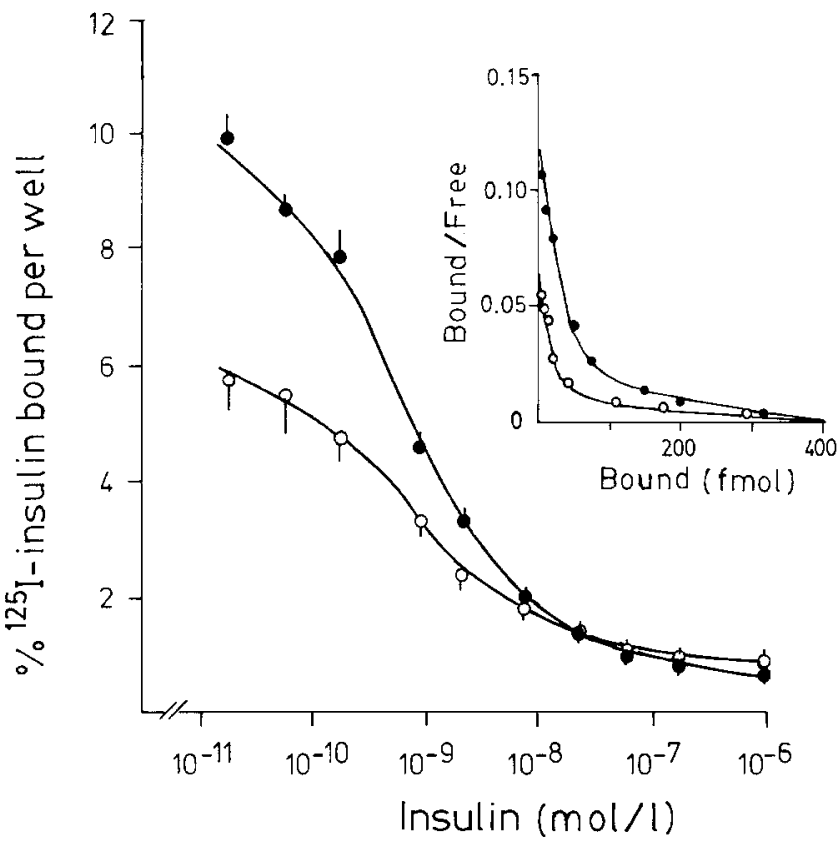

Fig. 1. Displacement curve of ${ }^{125}$ I-insulin binding. Fat cells were cultured in the absence $(\boldsymbol{O})$ or presence $(O)$ of dexamethasone $(20 \mathrm{nmol} / 1,72 \mathrm{~h})$. Subsequently, ${ }^{125} \mathrm{I}$-insulin binding was determined at $20^{\circ} \mathrm{C}$ in the presence of increasing amounts of native insulin. Inset: Scatchard plot of the binding data

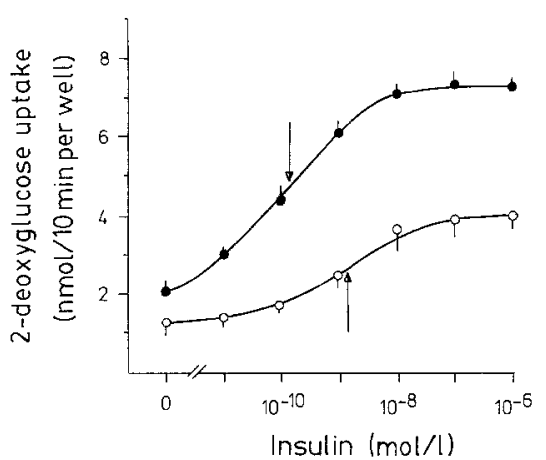

Fig. 2. Dose-response relationship of insulin-sensitive 2-deoxyglucose uptake. The uptake of 2-deoxyglucose in cells cultured in the absence $(-)$ or presence $(O)$ of dexamethasone $(20 \mathrm{nmol} / \mathrm{l}, 72 \mathrm{~h})$ was determined in the absence and presence of increasing amounts of insulin. The arrows indicate the half-maximal effective insulin concentration

incubated in $1.5 \mathrm{ml} \mathrm{Krebs-Ringer} \mathrm{Tris-} \mathrm{HCl}$ buffer ( $\mathrm{pH} 7.4)$ containing $2 \%$ bovine serum albumin. Then $18 \mathrm{pmol} / 1$ mono- $\mathrm{A}^{14}{ }_{-}{ }^{125} \mathrm{I}$-insulin $(2800 \mathrm{cpm} / \mathrm{fmol})$ was added and the cells were shaken $(75$ oscillations $/ \mathrm{min}$ ) at $20^{\circ} \mathrm{C}$ for $3 \mathrm{~h}$. Since in this period approximately $20 \%$ of the ${ }^{125} \mathrm{I}$-insulin was degraded by both the dexamethasone-treated $(20.1 \% \pm 0.7)$ and control $(22.3 \% \pm 1.3)$ cells, as determined by the TCA precipitation method [18], bacitracin $(1.5 \mathrm{mmol} / 1)$ was added to inhibit extracellular degradation. In the presence of bacitracin only $2-3 \%$ of the amount of insulin added was degraded during the incubation period. After the attainment of binding equilibrium $(3 \mathrm{~h})$ the cells were washed four times with $2 \mathrm{ml}$ ice-cold PBS, scraped off the dishes and treated with $1 \mathrm{ml}$ of $0.1 \mathrm{~mol} / 1 \mathrm{NaOH}$. Aliquots $(0.1 \mathrm{ml})$ were taken for protein determination [19], and ${ }^{125} \mathrm{I}$ was counted in a gamma counter (Packard Instruments, Downers Grove, Illinois, USA). Non-specific binding was defined as the amount of ${ }^{125} \mathrm{I}$ bound in the presence of an excess of native insulin $(1000 \mathrm{nmol} / \mathrm{l})$. The rate of association of the hormone to the receptor was determined by stopping the binding assay at appropriate times $(1-15 \mathrm{~min})$. The rate of dissociation was studied by adding a large volume $\left(0.2 \mathrm{ml} / \mathrm{cm}^{2}\right)$ of Tris buffer to the cells after the attainment of binding equilibrium. Every $10-15 \mathrm{~min}$ the buffer was replaced by fresh buffer and the amount of dissociated ${ }^{125}$ I counted.

\section{2-Deoxyglucose uptake}

Fat cells $\left(30 \mathrm{~mm}\right.$ wells, $5 \times 10^{5}$ cells) were incubated in $0.75 \mathrm{ml}$ Tris buffer in the presence or absence of insulin, at $37^{\circ} \mathrm{C}$. After $30 \mathrm{~min}$, 2-deoxyglucose-D- $\left(1-{ }^{14} \mathrm{C}\right)$-glucose $(0.1 \mathrm{mmol} / 1,710 \mathrm{cpm} / \mathrm{nmol})$, was added. The uptake was assayed during intervals in which uptake was linear with time (2-10 min), and was stopped by rinsing the wells four times with $1 \mathrm{ml}$ ice-cold PBS. The cells were treated as for insulin binding, except that ${ }^{14} \mathrm{C}$ was counted in al liquid scintillation counter (Packard Instruments, Downers Grove, Illinois, USA). The presence of cytochalasin $B(0.1 \mathrm{mmol} / \mathrm{l})$ in the termination procedure did not influence the 2-deoxyglucose uptake, indicating that efflux of label from the cells was not a predominant feature.

To determine the nature of the label in the cells, they were dissolved in $1.5 \mathrm{ml}$ of ice-cold Tris-Acetate buffer $(0.1 \mathrm{~mol} / \mathrm{l})$ containing Triton-X-100 $(0.2 \%)$, pH 7.8. This mixture was vortexed vigorously, and $1.5 \mathrm{ml}$ of iced chloroform was added for delipidization. After centrifugation at $2600 \mathrm{~g}$ for $10 \mathrm{~min}$ at $4{ }^{\circ} \mathrm{C}$, the supernatant, containing all the label taken up, was passed over a Dowex-1-chloride column $(3 \mathrm{~cm})$ in a pasteur pipette. The non-phosphorylated 2-deoxyglucose was removed from the column by washing with Tris buffer. The phosphorylated label was eluted with $\mathrm{HCl}(4 \mathrm{~mol} / \mathrm{l})$. By this procedure, the recovery of the labelled hexose was $97-104 \%$.

The intracellular waterspace was determined using a double-labelling technique. Fat cells were incubated in $1.5 \mathrm{ml}$ of Tris buffer $(\mathrm{pH}$ $\left.7.4,37^{\circ} \mathrm{C}\right)$. A time zero $3-\mathrm{O}$-methyl $\left({ }^{3} \mathrm{H}\right)$-glucose $\left(330 \mathrm{nmol} / 1 ; 10^{4}\right.$ $\mathrm{dpm} / \mathrm{pmol})$ and $\left(\mathrm{U}-{ }^{14} \mathrm{C}\right)$-sucrose $(800 \mathrm{nmol} / 1 ; 840 \mathrm{dpm} / \mathrm{pmol})$ were added. After 5 and $10 \mathrm{~min}$, when equilibrium was attained, the cells were rinsed four times with $2 \mathrm{ml}$ ice-cold PBS, containing phloretin $(0.1 \mathrm{mmol} / \mathrm{l})$ in order to remove all extracellular sugar. Phloretin was used to inhibit the efflux of methylglucose from the cell; it did in so far more than $95 \%$. The cells were then scraped off the dishes and dissolved in $0.1 \mathrm{~mol} / 1 \mathrm{NaOH} .{ }^{14} \mathrm{C}$ and ${ }^{3} \mathrm{H}$ were counted in a liquid scintillation counter (Packard Instruments, Downers Grove, Illinois, USA). The intracellular waterspace was calculated by subtracting the amount of sucrose from the amount of methylglucose. The intracellular non-phosphorylated 2-deoxyglucose concentration was calculated from the amount of non-phosphorylated 2-deoxyglucose in the cell and the intracellular waterspace. The hexokinase activity in the cells was determined as described previously [15].

\section{Determination of the cellular ATP content}

Cellular ATP levels were determined by bioluminescence. Cells (60 $\mathrm{mm}$ wells) were scraped off the dishes and dissolved in $1 \mathrm{ml}$ icecold Tris-acetate buffer $(0.1 \mathrm{~mol} / 1$ Tris $)$ containing EDTA $(2 \mathrm{mmol} / 1)$ and Triton-X-100 (0.2\%), $\mathrm{pH} 7.8$. After vigorous mixing, $250-\mu \mathrm{l}$ samples were transferred to microcentrifuge tubes and kept on ice. The tubes were centrifuged at $10,000 \mathrm{~g}$ for $10 \mathrm{~s}$. Fifty $\mu 1$ of the clear intermediate phase (containing all the ATP) were added to $50 \mu \mathrm{l}$ of luciferin-luciferase in a luminometer (Packard Instruments) and the bioluminescence was counted. The amount of ATP was calculated by the use of internal standards.

\section{Materials}

Culture media and sera were obtained from Gibco, Grand Island, New York, USA. Penicillin and streptomycin were from Gist Brocades, Rijswijk, The Netherlands. Demineralized bovine serum album was from Organon, Oss, The Netherlands. Mono- $\mathrm{A}^{14}{ }^{125} \mathrm{I}$-insulin (porcine and human) were generously provided by Eli Lilly, Nederland. Native monocomponent porcine insulin was from Novo, Co- 

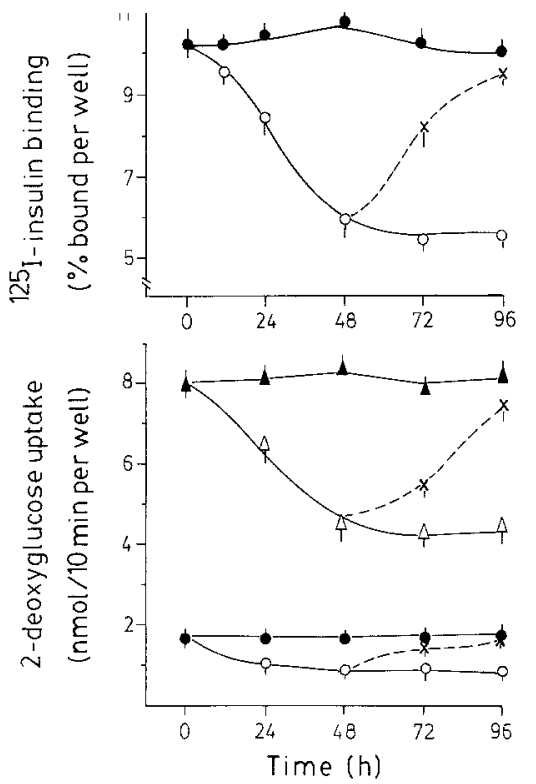

Fig.3. Time course and reversibility of the effects of dexamethasone on ${ }^{125} \mathrm{I}$-insulin binding and the 2-deoxyglucose uptake. Fat cells were cultured with $(O, \Delta)$ and without $(\bullet, \Delta)$ dexamethasone $(20 \mathrm{nmol} / 1)$ for several days. At the times indicated, ${ }^{125} \mathrm{I}$-insulin binding (upper panel) and basal $(O, O)$ or insulin-stimulated $(1000 \mathrm{nmol} / \mathrm{l})(\triangle, \mathbf{\Delta})$ 2-deoxyglucose uptake (lower panel) were determined. To test the reversibility, cells were first cultured in the presence $(O, \triangle)$ of dexamethasone and, subsequently, in the absence $(x)$ of the drug

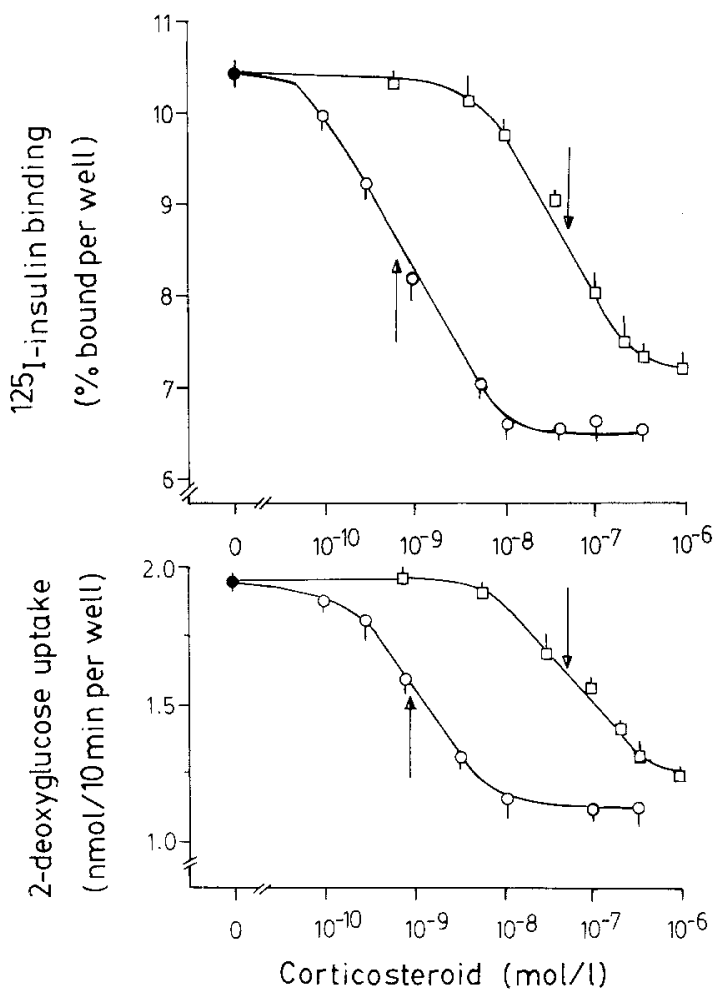

Fig.4. Concentration curve of the corticosteroid effect on ${ }^{125} \mathrm{I}$-insulin binding and the 2-deoxyglucose uptake. Fat cells were cultured in the presence of various concentrations of dexamethasone $(O)$ or corticosterone ( $\square$ ) for $72 \mathrm{~h}$. Subsequently, ${ }^{125} \mathrm{I}$-insulin binding (upper panel) and basal 2-deoxyglucose uptake (lower panel) were determined. The arrows indicate the half-maximal effective concentrations of the drugs penhagen, Denmark. 2-deoxy-D-(1-14 C)-glucose was purchased from New England Nuclear, Boston, Massachusetts, USA. (U- ${ }^{14} \mathrm{C}$ )-sucrose and 3-O-methyl- $\left({ }^{3} \mathrm{H}\right)$-glucose were from Amersham International, Amersham, Bucks, UK. 1-methyl-3-isobutylxanthine was from Aldrich Chemicals, Milwaukee, Wisconsin, USA, and cycloheximide form Serva, Heidelberg, FRG. Dexamethasone, corticosterone and cytochalasin B were from Sigma, St. Louis, Missouri, USA. Luciferinluciferase were obtained from Boehringer, Mannheim, FRG.

\section{Data analysis}

All data are expressed as mean \pm SEM. Where appropriate, the data were statistically analyzed by Student's t-test for paired comparison.

\section{Results}

Exposure of the cultured fat cells to dexamethasone $(20 \mathrm{nmol} / 1$ for $72 \mathrm{~h})$ decreased the ${ }^{125} \mathrm{I}$-insulin binding by up to $50 \%(n=6, p<0.001)$. This decrease in receptor occupancy was more pronounced at low insulin concentrations than at high ones (Fig. 1). At high insulin concentrations $(>50 \mathrm{nmol} / \mathrm{l})$ the amount of insulin bound to dexamethasone-treated cells sometimes even exceeded binding to control cells.

The decrease in insulin receptor binding was accompanied by substantial alterations in insulin-sensitive 2-deoxyglucose uptake (Fig. 2). Dexamethasone treatment ( $20 \mathrm{nmol} / 1$ for $72 \mathrm{~h}$ ) decreased 2-deoxyglucose uptake in the absence of insulin (basal uptake) by approximately $30 \%(n=7, p<0.001)$. In the presence of insulin, the reduction in rate of uptake was even more pronounced. The dose-response relationship shifted about eight-fold to the right $\left(\mathrm{ED}_{50}: 1.6 \pm 0.3\right.$ versus $0.2 \pm 0.1$ $\mathrm{nmol} / 1$ in dexamethasone-treated and control cells, respectively; $n=7 ; p<0.001$ ), indicating a decrease in insulin sensitivity, wheras the maximal insulin response (insulin responsiveness) was decreased by $40-50 \%$ $(n=7, p<0.001)$.

The effects of dexamethasone on insulin effectiveness varied with the length of the exposure to the drug. The time course for the alterations in insulin binding and in the basal and insulin-stimulated hexose uptake showed a marked resemblance (Fig. 3). They were maximal after $48-72 \mathrm{~h}$. When cells were cultured first in the presence of dexamethasone $(20 \mathrm{nmol} / 1$ for $48 \mathrm{~h})$ and subsequently in the absence of the drug, the alterations in insulin binding, hexose uptake and insulin responsiveness appeared to be completely reversible. Fortyeight hours after the removal of dexamethasone from the culture medium, original insulin binding and basal and insulin-stimulated 2-deoxyglucose uptake values were obtained (Fig. 3). In some experiments the reversal of basal hexose uptake appeared to precede the reversal of insulin responsiveness $(n=4, \mathrm{NS})$.

The effects of dexamethasone on insulin binding and the hexose uptake showed similar dose-dependence (Fig.4). Maximal effects were obtained at concentrations of $10-20 \mathrm{nmol} / 1$. Corticosterone, the native corticosteroid of mice, the species from which $3 \mathrm{~T} 3$ cells 


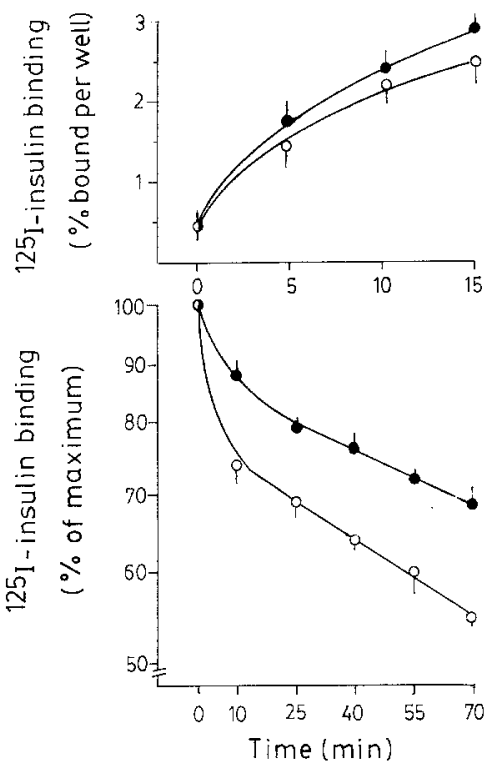

Fig. 5. Time course of the association and dissociation of ${ }^{125} \mathrm{I}$-insulin. Fat cells were maintained in the absence $(0)$ or presence $(O)$ of dexamethasone $(20 \mathrm{nmol} / 1)$ for $72 \mathrm{~h}$. In the association experiment (upper panel) the initial binding of ${ }^{125} \mathrm{I}$-insulin $(18 \mathrm{pmol} / \mathrm{l})$ was followed. After the attainment of binding equilibrium $\left(3 \mathrm{~h}, 20^{\circ} \mathrm{C}\right)$ the dissociation of insulin was followed for $70 \mathrm{~min}$ (lower panel)

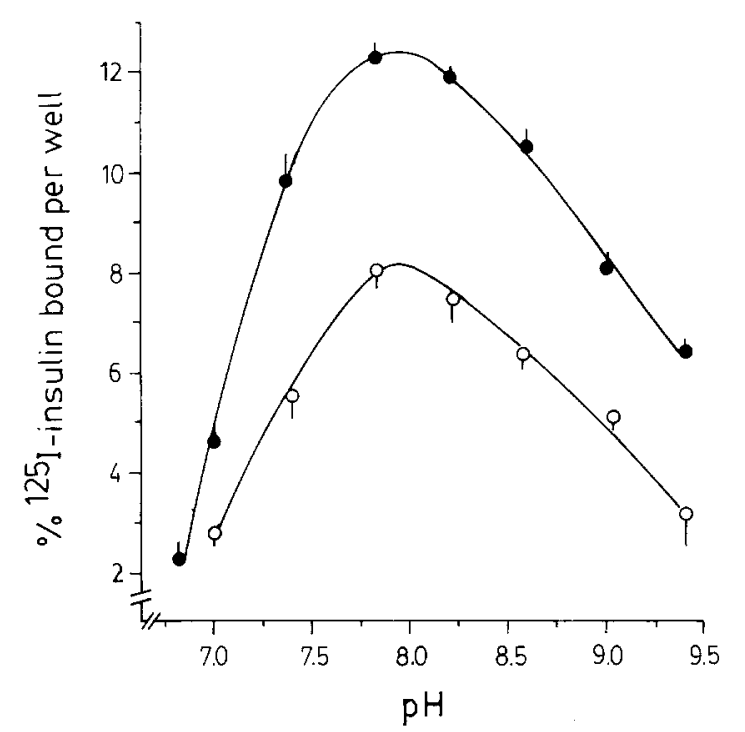

Fig. 6. $\mathrm{pH}$ dependence of the ${ }^{125} \mathrm{I}$-insulin binding. Fat cells were cultured with (O) and without $(\odot)$ dexamethasone $(20 \mathrm{nmol}, 72 \mathrm{~h})$. Subsequently, the $\mathrm{pH}$ dependence of the binding of ${ }^{125} \mathrm{I}$-insulin (18 pmol/ 1) was determined

originate, mimicked the effects of dexamethasone (Fig.4), though on a molar basis, corticosterone was about 60 times less potent than dexamethasone $\left(\mathrm{ED}_{50}\right.$ : $43 \pm 3$ versus $0.7 \pm 0.2 \mathrm{nmol} / 1)$. This difference in potency is comparable with the difference in biological activity between these compounds in vivo [20].

In an attempt to find more insight into the mechanism(s) by which corticosteroids regulate(s) the insulin effectiveness we tried to delineate the nature of the al- terations underlying the decrease in insulin binding and hexose uptake. Analysis of the binding data according to Scatchard (Fig. 1, inset) revealed that the dexamethasone-induced decrease in insulin binding was primarily due to a decrease in receptor affinity. The number of insulin receptors remained constant at approximately 126,000 receptors/cell. Kinetic experiments showed that dexamethasone increased the rate at which insulin dissociates from its receptors (Fig. $5 ; n=4, p<0.005$ ). The rate of association was hardly changed (Fig. 5, NS). Since $\mathrm{pH}$ and temperature are well-known factors that influence the affinity of receptors [21], we tested whether the effect of dexamethasone interfered with the effects of $\mathrm{pH}$ and temperature on insulin binding. The $\mathrm{pH}$ profile of insulin binding was identical before and after dexamethasone-treatment $(20 \mathrm{nmol} / 1$ for $72 \mathrm{~h})$ with an optimum at pH 7.8-8.0 (Fig. 6). Likewise, the effect of temperature on the affinity of binding sites was not altered. The $\mathrm{K}_{\mathrm{e}}$ (the affinity of the high affinity state or empty receptor) calculated according to De Meyts [22] changed from $0.45 \pm 0.09$ (control cells) and $0.23 \pm 0.06$ (dexamethasone-treated cells) at $20^{\circ} \mathrm{C}$ to $0.21 \pm 0.05$ (control cells) and $0.10 \pm 0.03$ (dexamethasone-treated cells) at $37^{\circ} \mathrm{C}(n=3)$. Apparently the effect of dexamethasone on the insulin binding was independent from those of $\mathrm{pH}$ and temperature.

The dexamethasone-induced alterations in the insulin-sensitive hexose uptake might result from changes in the components of the 2-deoxyglucose uptake process: transport of hexose across the membrane and formation of 2-deoxyglucose-6-phosphate (hexokinase reaction). The amount of intracellular ATP, which is of importance for the phosphorylation of the hexose as well as for the mediation of the effect of insulin, hardly changed upon dexamethasone treatment (Table I). The hexokinase activity on the other hand did decrease upon exposure to the drug (Table I). During the uptake of 2-deoxyglucose however, the intracellular concentration of non-phosphorylated 2-doxyglucose was always far below the extracellular concentration in the dexamethasone-treated $(20 \mathrm{nmol} / 1$ for $72 \mathrm{~h})$ and the control cells, as calculated from data on the intracellular waterspace and the nature of the labelled products inside the cells (Table 1). This indicates that transport rather than intracellular phosphorylation of hexose was the ratelimiting step in the 2-deoxyglucose uptake process. A decrease in the activity of the hexose transport system as induced by dexamethasone can be caused by an alteration in the number or activity of the hexose transporters, as well as by changes in their affinity. By analysis of the rate of uptake of various concentrations of 2-deoxyglucose $(0.05-5.0 \mathrm{mmol} / \mathrm{l})$ according to Lineweaver-Burk, it is possible to discriminate between these possibilities. Dexamethasone decreased the apparent $\mathrm{V}_{\max }$ of the transport system from $5.0 \pm$ $0.1 \mathrm{nmol} / \mathrm{min}$ per well in control cells to $3.2 \pm$ $0.2 \mathrm{nmol} / \mathrm{min}$ per well after $72 \mathrm{~h}$ of exposure to the drug $(20 \mathrm{nmol} / \mathrm{l} ; n=5, p<0.005)$. The apparent $\mathrm{K}_{\mathrm{m}} \mathrm{did}$ 
Table I. Characteristics of dexamethasone-treated and control cells

\begin{tabular}{lccl}
\hline & $\begin{array}{l}\text { Control } \\
\text { cells }\end{array}$ & $\begin{array}{l}\text { Dexametha- } \\
\text { sone- } \\
\text { treated cells }\end{array}$ & $p$ \\
\hline $\begin{array}{l}\text { 2-deoxyglucose uptake } \\
\text { (nmol/5 min per well) }\end{array}$ & $3.1 \pm 0.1$ & $2.3 \pm 0.1$ & $<0.001$ \\
$\begin{array}{l}\text { Intracellular waterspace } \\
\text { (ul/well) }\end{array}$ & $3.5 \pm 0.1$ & $3.3 \pm 0.1$ & $\mathrm{NS}$ \\
$\begin{array}{l}\text { Amount of intracellular } \\
\text { 2-deoxyglucose } \\
\text { (pmol/well,5 min) }\end{array}$ & $56.0 \pm 4.0$ & $34.0 \pm 3.0$ & $<0.005$ \\
$\begin{array}{l}\text { Intracellular 2-deoxyglucose } 14.6 \pm 0.4 \\
\text { concentration } \\
\text { (umol/1,5 min) }\end{array}$ & $10.4 \pm 0.3$ & $<0.005$ \\
$\begin{array}{l}\text { Hexokinase activity } \\
\text { (numol/5 min per well) }\end{array}$ & $54.0 \pm 1.8$ & $45.2 \pm 1.4$ & $<0.01$ \\
$\begin{array}{l}\text { Intracellular ATP values } \\
\text { (nmol/well) }\end{array}$ & $4.4 \pm 0.1$ & $4.0 \pm 0.2$ & $\mathrm{NS}$ \\
$\begin{array}{l}\text { Insulin binding } \\
\text { (\% bound/well) }\end{array}$ & $12.1 \pm 0.2$ & $8.1 \pm 0.4$ & $<0.001$ \\
$\begin{array}{l}\text { Cellular protein } \\
\text { content (mg/well) }\end{array}$ & $2.6 \pm 0.1$ & $2.4 \pm 0.1$ & $\mathrm{NS}$ \\
\hline
\end{tabular}

Fat cells were cultured in the presence $(10 \mathrm{nmol} / \mathrm{l}, 72 \mathrm{~h})$ or absence (control cells) of dexamethasone. All experiments were performed on $60 \mathrm{~mm}$ wells ( $\pm 2 \times 10^{6}$ cells $)$. Data are mean \pm SEM of at least three experiments

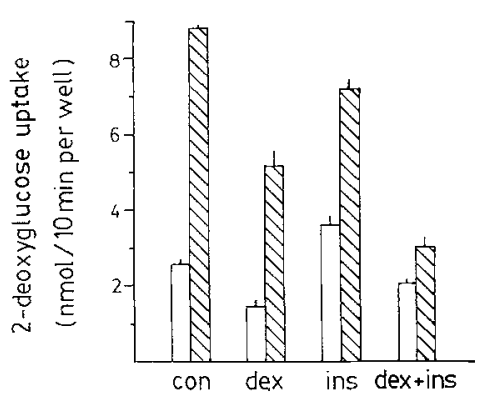

Fig. 7. Long-term effect of insulin and dexamethasone on the 2-deoxyglucose uptake. Fat cells were cultured in the absence (con) and presence of insulin (1000 nmol/1) (ins) and/or dexamethasone $(20 \mathrm{nmol} / 1)$ (dex) for $48 \mathrm{~h}$. Then the 2-deoxyglucose uptake was determined in the absence (open bars) and presence (hatched bars) of insulin $(1000 \mathrm{nmol} / 1)$

hardly change upon dexamethasone treatment $(2.0 \pm$ 0.1 versus $2.2 \pm 0.1 \mathrm{mmol}$ in dexamethasone-treated and control cells, respectively, NS). The decrease in the apparent $\mathrm{V}_{\max }$ (i.e. in the number or the activity of hexose transporters) was further explored by comparing the long-term effects of insulin and dexamethasone on hexose uptake. Prolonged exposure of the cells to insulin $(1000 \mathrm{nmol} / 1,48 \mathrm{~h})$ increases the basal hexose uptake and decreases the insulin response [15] (Fig. 7). The effects of dexamethasone appeared to be superimposed on the long-term effects of insulin. Dexamethasone decreased the insulin-induced increase in basal hexose uptake and further reduced the insulin-induced decrease in the maximal insulin-stimulated uptake (Fig. 7). Because of this apparent independence of the effects of dexamethasone and insulin we tested whether the in- duction of the effects of dexamethasone required protein synthesis, like the long-term insulin effect [15].

Treatment of the cells with dexamethasone $(20 \mathrm{nmol} / 1)$ and cycloheximide $(1 \mu \mathrm{g} / \mathrm{ml}$, an inhibitor of protein synthesis) for $20 \mathrm{~h}$ did not decrease the 2-deoxyglucose uptake in comparison with cells treated with cycloheximide alone $(0.9 \pm 0.1$ versus $0.7 \pm$ $0.1 \mathrm{nmol} / 5 \mathrm{~min}$ per $30 \mathrm{~mm}$ well, respectively). Moreover, the ${ }^{125}$ I-insulin binding was not reduced either (not shown). These data suggest that also for the induction of the effects of corticosteroids protein synthesis is a prerequisite.

\section{Discussion}

The data presented indicate that corticosteroids act as long-term regulators of insulin effectiveness in cultured 3T3 adipocytes. Treatment of cells with dexamethasone induced a time- and concentration-dependent and reversible decrease in insulin binding as well as in basal and insulin-stimulated 2-deoxyglucose uptake while corticosterone, the native hormone of mice, the species from which the cultured cells originate, mimicked the effects of dexamethasone. These observations confirm and further substantiate the findings of Grunfeld et al. [11], but contrast (partially) other in vitro studies. In isolated fat cells and adipose tissue explants, dexamethasone reduces hexose uptake but not insulin binding $[6$, 7]. This discrepancy with fat cells in culture might be related to perturbations of the fat cell isolation procedure, such as mechanical agitation and the use of digesting enzymes. In cultured cells of different origin (e. g. lymphocytes, fibroblasts) corticosteroids do influence insulin binding $[9,10]$, although in a way contrasting to that in 3 T3 adipocytes, suggesting cell type specificity. Our data in cultured fat cells fit well with observations in vi vo, despite differences in species. Both in rats and man, high plasma corticosteroid levels are accompanied by a decrease in insulin binding and action $[2,4,8$, 23].

Our observation that dexamethasone decreased the insulin binding by increasing the rate of dissociation of the hormone from the receptor can be explained by an alteration in the overall affinity of receptors and/or by a selective loss of high affinity binding sites. The latter is rather improbable considering the finding that the rate of association was hardly altered upon exposure to the drug. Recently, it has been suggested that the affinity of the receptor is regulated by the interaction of two functional components of the insulin receptor: a binding component and an affinity regulator [24]. $\mathrm{pH}$, temperature and the binding of insulin would change the affinity by influencing the interaction between these components $[25,26]$. The mechanism by which dexamethasone regulates the binding affinity is unknown, but appears to be independent from that of $\mathrm{pH}$ and temperature: the effect of $\mathrm{pH}$ and temperature did not change upon ex- 
posure to the drug. The finding that the effect of dexamethasone was inhibited by cycloheximide suggests the involvement of a protein synthesis-dependent regulatory process. This is not incompatible with an alteration in receptor affinity, considering the reports on a protein synthesis-dependent effect of dexamethasone on the lipid compositon of the plasma membrane [27-29]. The lipid composition of the membrane is an important determinant of the microviscosity ('fluidity') of the membrane, which is known to affect the characteristics of insulin receptor binding [30-33]. Whether dexamethasone regulates insulin binding by altering the fluidity of the membrane awaits further study.

The decrease in basal 2-deoxyglucose uptake accompanying dexamethasone treatment indicates the induction of post-receptor alterations i.e. alterations in the rate of transport and/or phosphorylation of hexose. In the dexamethasone-treated cells the decrease in the rate of uptake was possibly due to alterations in the hexose transport system, as indicated by the absence of substantial accumulation of non-phosphorylated 2-deoxyglucose in the cells during a period in which uptake was linear with time (i. e. in which there was no efflux of label). Moreover, on the assumption that there is no coupling between transport and the phosphorylation component of the 2-deoxyglucose uptake process, these data implicate that the observed decrease in hexokinase activity probably did not contribute to the decrease in basal hexose uptake. These findings are in agreement with previous observations demonstrating that in cultured fat cells 2-deoxyglucose transport rather than intracellular phosphorylation of the hexose appears to be the rate-limiting step in the 2-deoxyglucose uptake process [15] and, furthermore, that in rat fat cells the reduction in glucose transport primarily accounts for the dexamethasone-induced decrease in glucose oxidation $[6$, 34]. Lineweaver-Burk analysis of the uptake data revealed that the decrease in 2-deoxyglucose transport was due to a decrease in the apparent $V_{\max }$, i.e. in the number or activity of hexose transporters. Loci in the long-term regulation of hexose transport which might be affected by dexamethasone are the rate of de novo synthesis, the rate of (in)activation and/or the redistribution of hexose tranporters between the plasma membrane and an intracellular compartment. Prolonged exposure of the cells to insulin increases the rate of transport, probably by increasing the de novo synthesis of hexose transporters [15] and/or by a protein synthesisdependent redistribution of hexose transporters. The observation that the effects of dexamethasone on the basal and insulin-stimulated hexose transport seemed to be superimposed on the long-term insulin effect suggest that the effects of both compounds are mediated via different mechanisms. Glucose has been shown to regulate the hexose transport capacity by influencing the rate of inactivation (or degradation) of hexose transporters [17]. Preliminary data indicate that also the effects of glucose and dexamethasone are mediated by different mechanism. Obviously, further studies on the hexose transporter kinetics are required to unravel these mechanisms.

The decrease in the ability of insulin to stimulate basal 2-deoxyglucose uptake after dexamethasone treatment can partially (insulin sensitivity) be attributed to the decrease in insulin binding. The decrease in insulin responsiveness, however, cannot be explained by alteration in binding affinity. Even at high insulin concentrations, sufficient to fill up all binding sites necessary to elicit a maximal response, the insulin responsiveness was still decreased. Which process in the sequence of events between the binding of the hormone and its biological effect (i.e. the decrease in hexose uptake) is altered by dexamethasone remains to be solved. A lack of intracellular ATP, known to affect the insulin response, does not seem to be responsible, since the intracellular ATP values were not influenced by dexamethasone treatment. As mentioned, the effects of long-term exposure of the cells to insulin and dexamethasone on the maximal insulin-stimulated hexose uptake were synergistic. It is possible that the same alterations accounting for the decrease in basal hexose uptake are responsible for the decrease in insulin responsiveness. In fact, the resemblance in time course, concentration-dependence and reversibility of the effects of corticosteroids on the binding and uptake does suggest that the receptor- and postreceptor alterations are mediated via a common mechanism.

Acknowledgements. We wish to thank Wies Dijkstra-van der Star for her excellent technical assistance and Carina van den Haak for typing the manuscript. This work was granted by Foundation of Medical Research FUNGO, which is subsidized by the Netherlands Organization for the Advancement of Pure Research (ZWO).

\section{References}

1. Munck A (1971) Glucocorticoid inhibition of glucose uptake by peripheral tissues: old and new evidence, molecular mechanisms and physiological significance. Perspect Biol Med 14: 265-289

2. Olefsky JM, Johnson J, Liu F, Jen P, Reaven GH (1975) The effects of acute and chronic dexamethasone administration on insulin binding to isolated hepatocytes and adipocytes. Metabolism 24: 517-527

3. Kahn CR, Goldfine ID, Neville Jr DM, de Meyts P (1978) Alterations in insulin binding induced by changes in vivo in the levels of glucocorticoids and growth hormone. Endocrinology 103: 1054-1066

4. Yasuda K, Hines III E, Kitabchi AE (1982) Hypercortisolism and insulin resistance: comparitive effects of prednisone, hydrocortisone and dexamethasone on insulin binding of human erythrocytes. J Clin Endocrinol Metab 55: 910-915

5. Fantus IG, Ryan J, Hizuka N, Gorden P (1981) The effect of glucocorticoids on the insulin receptor: an in vivo and in vitro study. $J$ Clin Endocrinol Metab 52: 953-960

6. Olefsky JM (1975) Effect of dexamethasone on insulin binding, glucose transport and glucose oxidation of isolated rat adipocytes. J Clin Invest 56: 1499-1508

7. Malchoff DM, Maloff BL, Livingston JN, Lockwood DH (1982) Influence of dexamethasone on insulin action: inhibition of basal and insulin stimulated hexose transport is dependent on length of exposure in vitro. Endocrinology 110: 2081-2087 
8. de Pirro R, Green A, Yung-Chin Khoo M, Olefsky JM (1981) Effects of prednisolone and dexamethasone in vivo and in vitro: studies of insulin binding, deoxyglucose uptake and glucose oxidation in rat adipocytes. Diabetologia 21: 149-153

9. Fantus IG, Saviolakis GA, Hedo JA, Gorden P (1982) Mechanism of glucocorticoid-induced increase in insulin receptors of cultured human lymphocytes. J Biol Chem 257: 8277-8283

10. Knutson VP, Ronnett GV, Lane DM (1982) Control of insulin receptor level in 3T3 cells: effect of insulin-induced down-regulation and dexamethasone-induced up-regulation on rate of receptor inactivation. Proc Natl Acad Sci USA 79: 2822-2826

11. Grunfeld C, Baird K, van Obberghen E, Kahn CR (1981) Glucocorticoid-induced insulin resistance in vitro: evidence for both receptor and postreceptor defects. Endocrinology 109:1723-1730

12. Livingston JN, Lockwood DH (1975) Effect of glucocorticoids on the glucose transport system of isolated fat cells. J Biol Chem 250: $8353-8360$

13. Green $H$ (1979) Adipose conversion: a program of differentiation, In: Ailhaud C (ed) Obesity, cellular and molecular aspects, vol 87. Inserm, Nice, pp 15-24

14. Rosen OM, Smith CJ, Hirsch A, Lai E, Rubin CS (1979) Recent studies of the $3 \mathrm{~T} 3-\mathrm{L}_{1}$ adipocyte-like cell line. Rec Prog Horm Res 35: $477-500$

15. van Putten JPM, Wieringa Tj, Krans HMJ (1985) Long-term regulation of hexose transport by insulin in cultured mouse $3 \mathrm{~T} 3$ adipocytes. Diabetologia 28: 51-57

16. Grunfeld C, Baird KL, Kahn CR (1981) Maintenance of 3T3-L $\mathrm{L}_{1}$ cells in culture media containing saturated fatty acids decreases insulin binding and insulin action. Biochem Biophys Res Commun 103: 219-226

17. van Putten JPM, Krans HMJ (1985) Glucose as a regulator of insulin-sensitive hexose uptake in $3 \mathrm{~T} 3$ adipocytes. J Biol Chem (in press)

18. Freychet P, Kahn CR, Roth J, Neville DM Jr (1972) Insulin interactions with liver plasma membrane. J Biol Chem 247: 3953-3961

19. Sedmak JJ, Grossberg SE (1977) A rapid, sensitive and versatile assay for protein using Coomassie Brillant Blue G 250. Anal Biochem 79: 544-553

20. Munck A, Young DA (1975) Corticosteroids and lymphoid tissue. In: Geiger SR (ed) Handbook of physiology. Waverly Press, Baltimore, pp 231-243

21. Cuatrecasas $P$ (1971) Properties of the insulin receptor of isolated fat cell membranes. J Biol Chem 246: 7265-7274

22. DeMeyts P, Roth J (1975) Cooperativity in ligand binding: a nerw graphic analysis. Biochem Biophys Res Commun 66: 1118-1126

23. de Pirro R, Bertoli A, Fusco A, Testa A, Grevo AV, Lauro R (1980)
Effect of dexamethasone and cortisone on insulin receptors in normal human male. J Clin Endocrinol Metab 51: 503-507

24. Harmon JT, Kahn CR, Kempner ES, Schlegel W (1980) Characterization of the insulin receptor in its membrane environment by radiation inactivation. J Biol Chem 255:3412-3419

25. Harmon JT, Kampner ES, Kahn CR (1981) Demonstration by radiation inactivation that insulin alters the structure of the insulin receptor in rat liver membranes. J Biol Chem 256: 7719-7722

26. Harmon JT, Hedo JA, Kahn CR (1983) Characterization of a membrane regulator of insulin receptor affinity. $\mathrm{J}$ Biol Chem 258 : 6875-6881

27. Murray DK, Ruhman-Wennhold A, Nelson DH (1979) Dexamethasone effects on the phospholipid content of isolated fat cell ghosts from adrenalectomized rats. Endocrinology 105: 774-777

28. Nelson DM, Murray DK (1982) Dexamethasone increases the synthesis of sfingomyeline in 3 T3 cell membranes. Proc Natl Acad Sci USA 79: 6690-6692

29. Murray DK, Ruhman-Wennhold A, Nelson DH (1982) Adrenalectomy decreases the sphingomyelin and cholesterol content of fat cell ghosts. Endocrinology 111: 452-455

30. Ginsberg BH, Brown TJ, Simon I, Spector AA (1981) Effect of membrane lipid environment on the properties of insulin receptors. Diabetes 30: $773-780$

31. Gould RJ, Ginsberg BH, Specotr AA (1982) Lipid effects on the binding properties of a reconstituted insulin receptor. J Biol Chem 257: 477-484

32. McCaleb ML, Donner DB (1981) Affinity of the hepatic insulin receptor is influenced by membrane phospholipids. J Biol Chem 256: 11051-11057

33. Wieringa Tj, de Bruin G, van Meerwijk WPM, Krans HMJ (1982) Effect of purified phospholipases on glucose transport, insulin binding and insulin action in isolated rat adipocytes. Cell Biophys 4: 261-271

34. Czech MP, Fain JN (1971) Antagonism of insulin action on glucose metabolism in white fat cells by dexamethasone. Endocrinology $91: 518-522$

Received: 30 January 1985

and in revised form: 11 June 1985

Professor H.M.J.Krans

Department of Endocrinology and Metabolic Diseases

University Hospital, Bldg. 30

NL-2333 AA Leiden

The Netherlands 